TECHNO

Vol.20, No.2, Oktober 2019, Hal. 105 116

P-ISSN: 1410-8607, E-ISSN: 2579-9096

\title{
SPEED CONTROL SERIES DC MOTOR USING ANT COLONY OPTIMIZATION
}

\author{
Muhammad Ruswandi Djalal ${ }^{1 *}$, Herman HR $^{2}$ \\ ${ }^{1,2}$ Teknik Pembangkit Energi, Jurusan Teknik Mesin, Politeknik Negeri Ujung Pandang
}

\begin{tabular}{|c|c|}
\hline Informasi Makalah & INTISARI \\
\hline $\begin{array}{l}\text { Dikirim, } 8 \text { Juni } 2019 \\
\text { Direvisi, } 12 \text { September } 2019 \\
\text { Diterima, } 12 \text { September } 2019\end{array}$ & $\begin{array}{l}\text { Motor DC yang terhubung dengan seri atau shunt banyak digunakan dalam } \\
\text { berbagai aplikasi. Karena memiliki torsi yang relatif tinggi untuk memikul } \\
\text { beban dibandingkan dengan motor permanen magnet dengan ukuran yang } \\
\text { sama. Motor permanen magnet bersifat linear sedangkan motor DC bersifat } \\
\text { non linear. Karakteristik non linear dari motor DC seperti saturasi dan } \\
\text { gesekan dapat menurunkan kinerja dari konvensional Kontrol. Algoritma Ant }\end{array}$ \\
\hline $\begin{array}{l}\text { Kata Kunci: } \\
\text { PID } \\
\text { Ant Colony Optimization } \\
\text { Overshoot } \\
\text { Settling time } \\
\text { Motor DC Seri }\end{array}$ & $\begin{array}{l}\text { Coloni pada prinsipnya mencari sumber makanan berdasarkan jejak } \\
\text { feromone yang kemudian secara berkelompok akan mengikuti jejak yang } \\
\text { memiliki feromone yang terbesar. Dengan prinsip ini algoritma akan mencari } \\
\text { parameter yang paling optimal untuk diisikan pada parameter PID, sehingga } \\
\text { didapatkan kendali optimal pada kecepatan Motor DC Seri. Hasil optimasi } \\
\text { ant colony didapatkan nilai fitness function sebesar } 111.8087 \text {, dengan } 50 \text { kali } \\
\text { iterasi, dan parameter nilai PID yang optimal di mana, parameter P } \\
\text { (Proportional) sebesar 23.0337, I (Integral) sebesar 7.9168, dan D } \\
\text { (Derivative) sebesar 7.8163. Dengan beberapa case kecepatan dan perubahan } \\
\text { beban pada Motor DC Seri, dengan kendali PID Ant Colony didapatkan } \\
\text { kinerja system optimal dengan overshoot yang minimum dan settling yang } \\
\text { cepat. }\end{array}$ \\
\hline
\end{tabular}

Keyword:

PID

Ant Colony Optimization

Overshoot

Settling time

Series DC Motor

\begin{abstract}
DC motors connected with series or shunt are widely used in various applications. Because it has a relatively high torque to carry the load compared to permanent magnet motors of the same size. Permanent motors are linear while DC motors are non linear. Non-linear characteristics of DC motors such as saturation and friction can reduce performance from conventional controls. The Ant Coloni algorithm in principle searches for food sources based on traces of feromone which then in groups will follow the footsteps that have the largest feromone. With this principle the algorithm will look for the most optimal parameters to be filled in the PID parameters, so that optimal control is obtained at the speed of the DC Motor Series. The results of the ant colony optimization obtained a fitness function value of 79.4892, with 50 iterations, and the optimal PID value parameter where, the $\mathrm{P}$ (Proportional) parameter is 23.0337, I (Integral) of 7.9168, and D (Derivative) 7.8163. With several cases of speed and load changes in the DC Motor Series, with the PID Ant Colony control, optimal system performance is achieved with minimum overshoot and fast settling.
\end{abstract}

Korespondensi Penulis:

Muhammad Ruswandi Djalal

Teknik Pembangkit Energi

Politeknik Negeri Ujung Pandang

Jalan Perintis Kemerdekaan km.10, Makassar, 90245.

Email: wandi@poliupg.ac.id 


\section{PENDAHULUAN}

Motor DC yang terhubung dengan seri atau shunt banyak digunakan dalam berbagai aplikasi. Karena memiliki torsi yang relatif tinggi untuk memikul beban dibandingkan dengan motor permanen magnet dengan ukuran yang sama. Motor permanen magnet bersifat linear sedangkan motor DC bersifat non linear. Ketidaklinearan dari motor DC tersebut akan mempersulit dalam aplikasi yang memerlukan kecepatan kontrol secara otomatis. Sayangnya, non linear model dinamik dari motor DC memiliki keterbatasan pada desain dari ragkaian close-loop feedback kontroler. Karakteristik non linear dari motor DC seperti saturasi dan gesekan dapat menurunkan kinerja dari konvensional Kontrol [1, 2].

Penggunaan kontrol berbasis Proportional Integral Derivative (PID) pada kontrol proses sudah semakin banyak, karena keandalan dan strukturnya sederhana dan stabilitas yang baik. PID banyak digunakan bersama dengan Motor DC Seri dalam aplikasi industri. Namun pada penerapannya penyesuaian parameter PID menjadi kompleks dan dibeberapa tahun terakhir telah banyak metode untuk penalaan parameter PID. Dalam aplikasinya secara sederhana, digunakan metode penalaan trial-error untuk menyesuaikan nilai PID, namun untuk metode ini sulit untuk mendapatkan nilai optimal sehingga sulit untuk menyesuaikan parameter, serta dibutuhkan waktu yang lama [3], dan juga akurasi kontrol tidak baik.

Dalam beberapa tahun terakhir, para peneliti telah banyak menggunakan metode cerdas (Artificial Intelligent) untuk penentuan parameter PID dari Motor DC Seri. Para peneliti mulai mempelajari perilaku cerdas dari hewan, dan diterapkan untuk diaplikasikan menyelesaikan permasalahan optimasi, terkhusus pada bidang kontrol. Hewan tersebut diantaranya lebah, semut, tawon dan menemukan suatu algoritma perilaku dari kebiasaan atau perilaku dari hewan tersebut.

Ant-Colony Optimization termasuk dalam kelompok Swarm Intelligence, yang merupakan salah satu jenis pengembangan paradigma yang digunakan untuk menyelesaikan masalah optimasi dimana inspirasi yang digunakan untuk memecahkan masalah tersebut berasal dari perilaku kumpulan atau kawanan (swarm) serangga [4]. Setiap semut dalam kawanan yang berjalan akan meninggalkan pheromone (semacam zat kimia) pada jalur yang dilaluinya. Pheromone ini menjadi semacam sinyal bagi sesama semut. Jalur yang pendek akan menyisakan sinyal yang lebih kuat. Semut berikutnya, pada saat memutuskan jalur mana yang harus dipilih, biasanya akan cenderung memilih untuk mengikuti jalur dengan sinyal yang paling kuat, sehingga jalur terpendek akan ditemui karena lebih banyak semut yang akan melewati jalur tersebut.Semakin banyak semut yang lewat suatu jalur, semakin kuat sinyal di jalur itu. Penggunaan metode ACO juga digunakan pada penelitian ini sebagai metode untuk menala parameter PID.

Beberapa metode optimasi berbasis metode konvensional maupun metode cerdas telah banyak digunakan untuk mengoptimasi parameter PID Motor DC Seri, diantaranya Artificial Bee Colony [5], Particle Swarm Optimization [6], Cuckoo Search, Particle Swarm, Neural Network, Firefly dan Flower Pollination, diantaranya [3, 7-13].

Pada penelitian ini akan digunakan metode cerdas (Artificial Intelligent) lain untuk menala parameter PID Motor DC Seri yaitu dengan metode Ant Colony Optimization (ACO) dan akan dianalisa dan dibandingkan respon kecepatan Motor DC Seri dengan metode konvensional PID trial-error serta Motor DC Seri tanpa kontroler.

\section{MOTOR DC SERI}

Motor DC adalah mesin listrik yang mengkonsumsi daya listrik DC sehingga menghasilkan torsi mekanik. Secara historis, Mesin DC diklasifikasikan berdasarkan koneksi (hubungan) dari rangkaian field dan rangkaian armature. Pada motor DC seri, rangkaian field dihubungkan seri dengan rangkaian armature dimana kedua arus field dan arus armature adalah identik atau sama. Pada motor DC seri memiliki karakteristik starting torsi yang tinggi yang membuatnya cocok untuk aplikasi yang memiliki inertia serta sistem traksi tinggi dan memiliki non linear model yang dinamik. Adapun rangkaian equivalen dari motor DC seri ditunjukan oleh Gambar 2.1 sebagai berikut [14]:

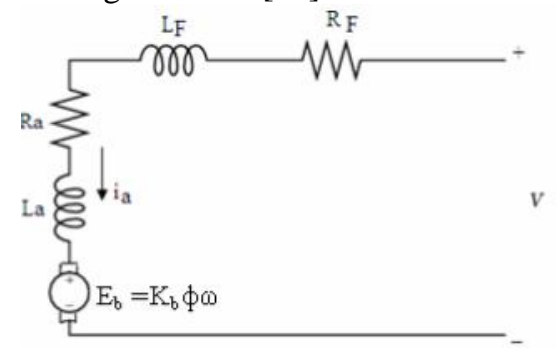

Gambar 1 Rangkaian equivalen Motor DC seri 
Persamaan pada rangkaian armature sebagai berikut:

$$
\left(L_{a}+L_{f}\right) \frac{d i_{a}}{d t}=V-\left(R_{a}+R_{f}\right) i_{a}=K_{b} \phi \omega
$$

Persamaan motion dari motor DC sebagai berikut [2] :

$$
J \frac{d \omega}{d t}=K_{t} \phi i_{a}-T_{L}
$$

Dimana :
$\mathrm{L}_{\mathrm{a}}=$ Induktansi armature winding
$\mathrm{L}_{\mathrm{f}}=$ Induktansi field winding
$\mathrm{R}_{\mathrm{a}}=$ Resistansi armature winding
$\mathrm{R}_{\mathrm{f}}=$ Resistansi field winding
$\mathrm{I}_{\mathrm{a}}=$ Arus armature
$\mathrm{K}_{\mathrm{b}}=$ Konstanta desain dari mesin
$\phi \quad=$ Fluks medan magnet
$\mathrm{V}=$ Tegangan terminal
$\mathrm{Kt}=$ Konstanta torsi
$\mathrm{J} \quad=$ Rotor dan Beban inertia
$\mathrm{T}_{\mathrm{L}}=$ Torsi beban
$\omega=$ Kecepatan rotasi dari rotor

\subsection{Pemodelan Motor DC Seri}

Pemodelan Motor DC Seri yang digunakan mengacu pada sebuah paper yang di mana menggunakan pemodelan transfer function. Motor DC Seri yang digunakan di sini adalah menggunakan Motor DC Seri [14].

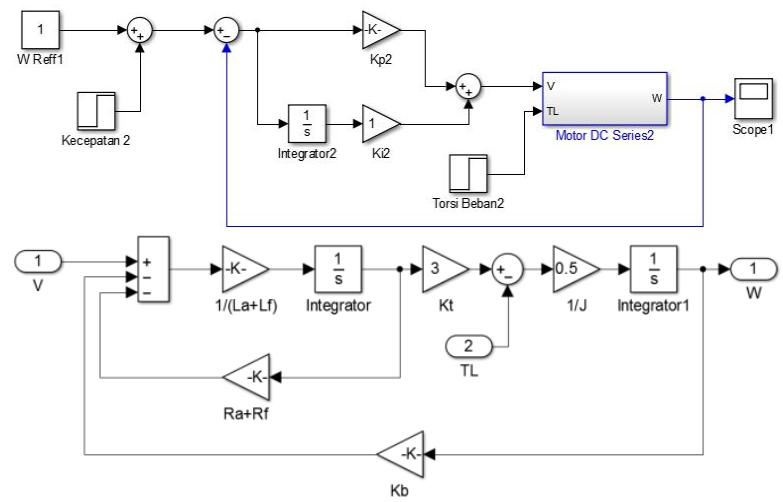

Gambar 2. Pemodelan Motor DC Seri di Simulink

\subsection{Pemodelan Kontroler PID}

Kontrol PID adalah salah satu kontrol yang sudah banyak digunakan pada aplikasi industri karena strukturnya yang sederhana [3].

$$
u(t)=k_{p}\left[e(t)+\frac{1}{T_{i}} \int_{0}^{t} e(t) d t+T_{d} \frac{d e_{t}}{d t}\right]
$$

Di mana, $\mathrm{u}(\mathrm{t})$ adalah nilai kontrol yang dihitung oleh kontroler PID, Kp adalah koefisien proporsional, $\mathrm{Ti}$ adalah integral waktu konstan dan $\mathrm{Td}$ adalah diferensian time konstan. Fungsi dari ketiga elemen tersebut adalah :

- Proporsional: menggambarkan sinyal deviasi e (t) dari sistem kontrol proporsional. ketika sinyal e(t) ada, kontroler PID menghasilkan efek kontrol segera untuk mengurangi penyimpangan.

- Integral : digunakan untuk menghilangkan kesalahan statis dan meningkatkan stabilitas sistem.

- Diferensial : mencerminkan perubahan penyimpangan sinyal, memperkenalkan sinyal koreksi sebelum penyimpangan nilai sinyal menjadi lebih besar dan mempercepat respon sistem untuk mengurangi pengaturan waktu.

Oleh karena itu, merancang kontroler PID terutama berarti menentukan tiga parameter, serta bagaimana mengkonfigurasi ke tiga parameter PID (Kp, Ki, Kd). Dalam penelitian ini, Ant Colony diusulkan untuk mencari parameter optimal PID. Blok diagram sistem kontrol ditunjukkan pada gambar 3. 


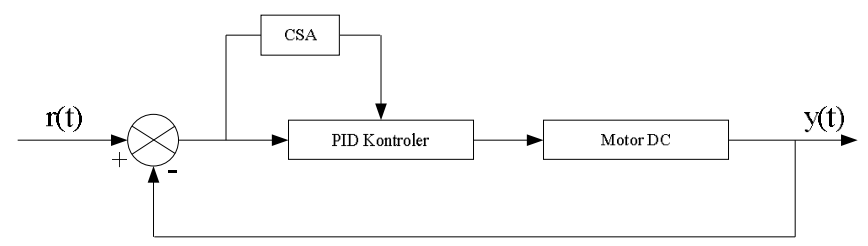

Gambar 3. Sistem Kontroler PID

\section{METODE PENELITIAN}

\subsection{Ant Colony Optimization}

\section{Penentuan Jarak Antar Kota}

Kota yang dimaksud di sini adalah besarnya nilai pembangkitan dari masing-masing pembangkit. Sebelum dilakukan perjalanan, jarak antara nilai dari pembangkitan pembangkit yang satu dengan pembangkit yang lainnya dihitung terlebih dahulu (diinisialisasi). Setelah dilakukan inisialisasi, maka semut diletakkan di kota pertama tertentu secara acak. Kemudian semut akan melanjutkan perjalanannya dari satu kota ke kota yang lainnya secara acak sampai ke tujuan akhir, yaitu kota terakhir. Setelah perjalanan selesai, lokasi kota-kota yang telah dilalui oleh semut akan digunakan untuk menghitung solusi yang dihasilkan dari perjalanan tersebut .

\section{Perjalanan Semut}

Semut memilih suatu jalur yang akan dilalui mulai dari titik $r$ menuju ke titik $s$ dalam suatu perjalanan dengan probabilitas :

$$
\mathrm{p}(\mathrm{r}, \mathrm{s})=\frac{\gamma(\mathrm{r}, \mathrm{s})}{\sum_{\mathrm{t}} \gamma(\mathrm{r}, \mathrm{l})} \mathrm{s}, 1 \in \mathrm{N}_{\mathrm{r}}^{\mathrm{k}}
$$

matrix $\gamma(\mathrm{r}, \mathrm{s})$ merepresentasikan jumlah intensitas feromon antara titik $\mathrm{r}$ dan $\mathrm{s}$. Kemudian feromon akan diperbaharui melalui persamaan berikut :

$$
\gamma(\mathrm{r}, \mathrm{s})=\alpha \cdot \gamma(\mathrm{r}, \mathrm{s})+\Delta \mathrm{y}^{\mathrm{k}}(\mathrm{r}, \mathrm{s})
$$

dimana $\alpha$ dengan interval $0<\alpha<1$ merupakan daya tahan suatu feromon, maka (1- $\alpha)$ merepresentasikan penguapan yang terjadi pada feromon dan $\Delta \gamma^{\mathrm{k}}(\mathrm{r}, \mathrm{s})$ merupakan jumlah feromon yang semut $\mathrm{k}$ jatuhkan pada jalur $(\mathrm{r}, \mathrm{s})$.

\section{Perbaharui Feromon Lokal}

Jejak feromon $(r, s)$ untuk perjalanan terbaik yang telah dilakukan semut (semut yang menghasilkan parameter optimal PID) akan diperbaharui dengan menggunakan persamaan berikut.

$$
\gamma(\mathrm{r}, \mathrm{s})=\alpha \cdot \gamma(\mathrm{r}, \mathrm{s})+\frac{\mathrm{Q}}{\mathrm{f}_{\text {best }}} \mathrm{r}, \mathrm{s} \in \mathrm{J}_{\text {best }}^{\mathrm{k}}
$$

dengan $Q$ merupakan sebuah konstanta positif yang sangat besar nilainya.

\section{Perbaharui Feromon Global}

Untuk menghindari terjadinya stagnan (suatu situasi dimana semut akan mengikuti jalur yang sama, yang mana akan menghasilkan solusi yang sama), maka kekuatan jejak feromon dibatasi pada interval berikut

$$
\gamma(\mathrm{r}, \mathrm{s})=\left\{\begin{array}{cl}
\tau_{\min } & \text { if } \gamma(\mathrm{r}, \mathrm{s}) \leq \tau_{\min } \\
\tau_{\max } & \text { if } \gamma(\mathrm{r}, \mathrm{s}) \geq \tau_{\max }
\end{array}\right\}
$$

Batasan atas dan batas bawahnya adalah sebagai berikut :

$$
\begin{gathered}
\tau_{\text {max }}=\frac{1}{\alpha \cdot f_{\text {best }}} \\
\tau_{\text {min }}=\frac{\tau_{\text {max }}}{M^{2}}
\end{gathered}
$$

dengan $\mathrm{M}$ adalah jumlah semut yang melakukan perjalanan.

Techno Vol. 20, No. 2, Oktober 2019: $105-116$ 


\section{Plot Perjalanan Semut}

Solusi dari perjalanan koloni semut dalam optimasi parameter PID diplot ke dalam sebuah grafik sampai batas maksimum iterasi.

\section{Plot Perjalanan Terbaik}

Perjalanan dengan solusi terbaik dari koloni semut (parameter optimal PID) untuk setiap iterasi diplot sampai batas iterasi maksimum.

\section{Flowchart Ant Colony Optimization}

Diagram alir (flowchart) dari metode Ant Colony Optimization yang digunakan untuk mencari parameter optimal PID ditunjukkan pada gambar 5.

\section{Parameter Ant Colony Optimization}

Beberapa parameter yang digunakan pada metode Ant Colony Optimization pada tesis ini adalah sebagai berikut:

- Jumlah semut $=10$

- Iterasi maksimum = 50

- $\operatorname{Ketahan}$ feromon(alpha) $=0.9$

\section{Inisialisasi Feromon (Matriks Tau)}

Matriks tau ini memiliki ukuran $\mathrm{n} \times \mathrm{m}$, dengan $\mathrm{n}$ adalah banyaknya kontroler pada sistem, sedangkan $\mathrm{m}$ adalah banyaknya parameter PID dengan skala 0 sampai dengan 1 yang memiliki interval 0,01. Nilai dari matriks ini akan diperbaharui setiap dilakukan perjalanan oleh koloni semut.

\section{Penalaan Kontrol PID dengan Ant Colony}

Gambar 4 menunjukkan diagram alir algoritma metode Ant Colony yang digunakan pada penelitian ini untuk menala parameter PID. Fungsi objektif yang digunakan untuk menguji kestabilan sistem adalah dengan Integral Time Absolut Error (ITAE).

$$
\text { ITAE }=\int_{0}^{t} t|\Delta \omega(t)| d t
$$

Parameter PID yang ditala oleh Ant Colony adalah Kp, Ki dan Kd. Adapun untuk diagram alir proses penalaan parameter PID dengan menggunakan metode Ant Colony ditunjukkan oleh flowchart pada Gambar 5 dan gambar 4 menunjukkan pemodelan Motor DC Seri pada Simulink Matlab 2013, tanpa kontrol, dengan PID Trial dan PID Ant Colony.

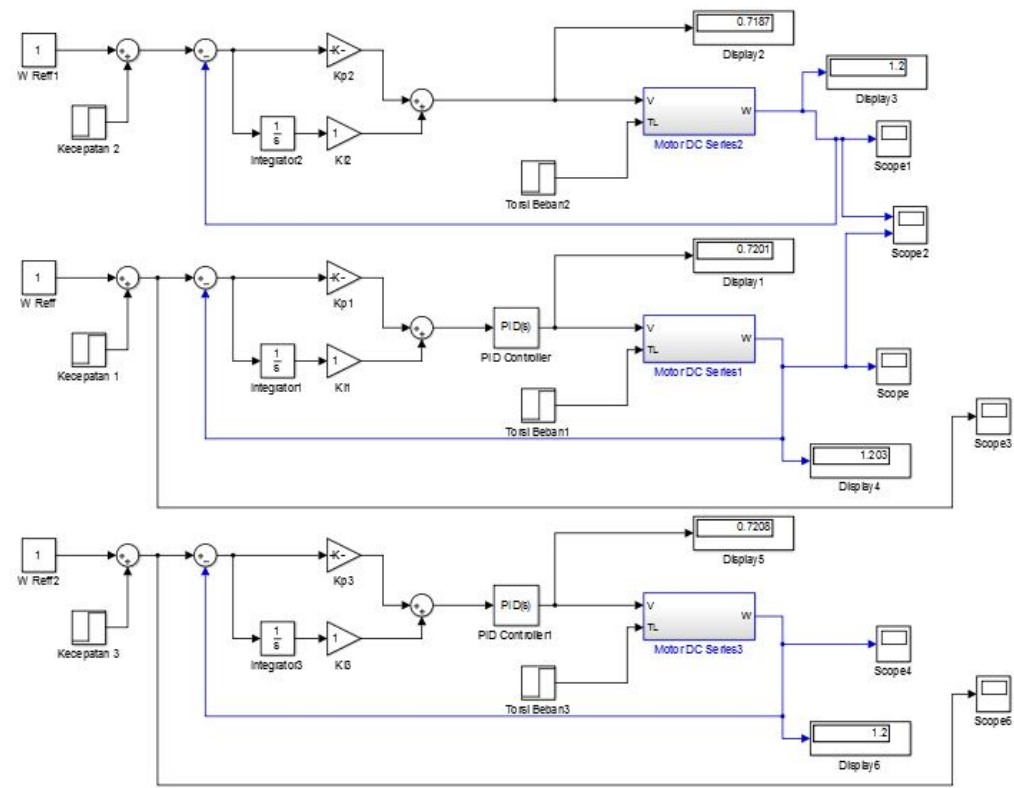

Gambar 4. Pemodelan Motor DC Seri di Simulink 
Untuk menjalankan algoritma Ant Colony dibutuhkan beberapa parameter, yang disebutkan pada table berikut ini. Algoritma ant colony dibuat menggunakan software Matlab (m.files) dan pemodelan motor menggunakan Simulink Matlab. Adapun data parameter-parameter ant colony adalah berikut,

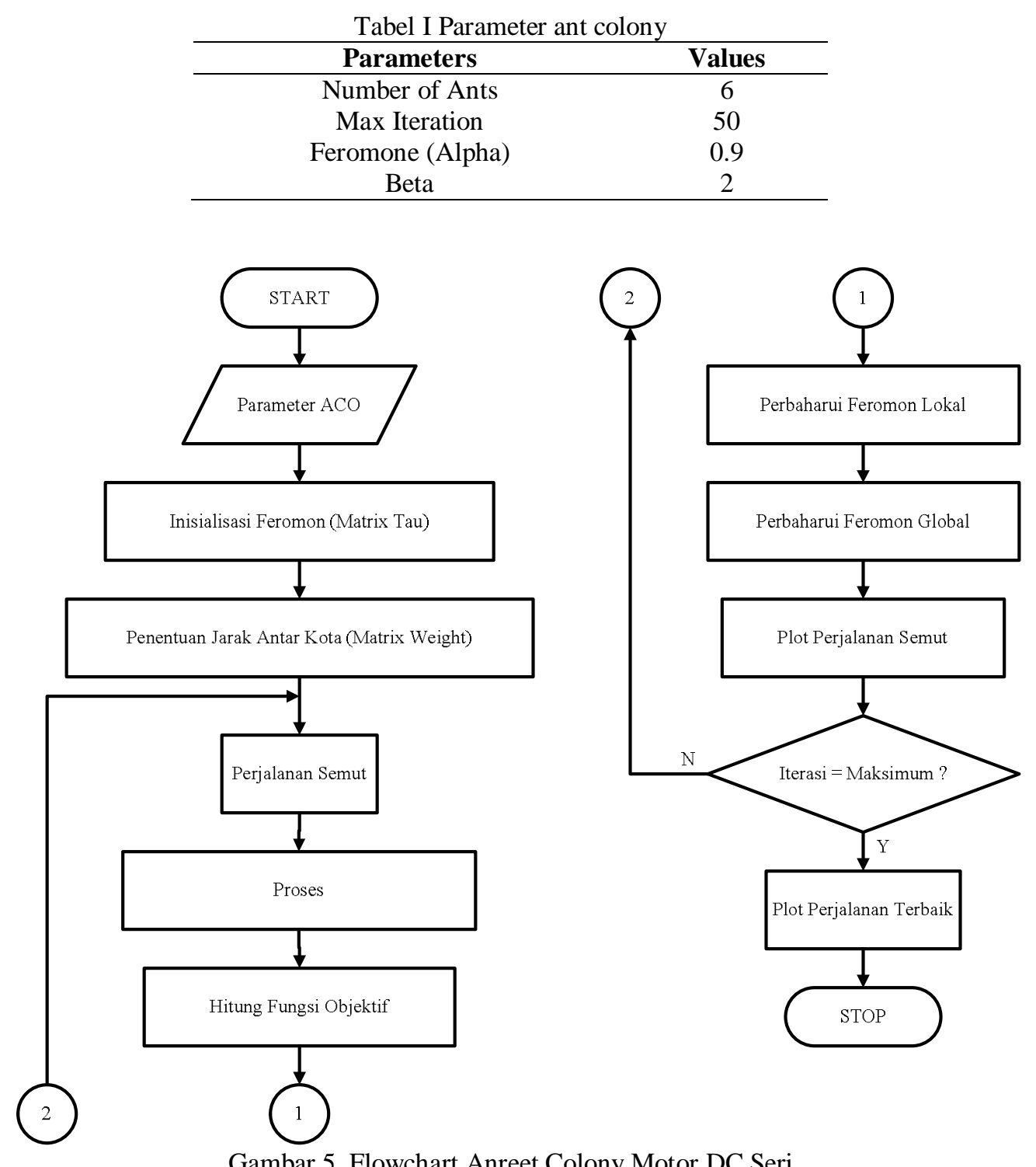

Setelah memasukkan beberapa parameter tersebut di table di atas, maka selanjutnya algoritma ant colony dijalankan untuk optimasi nilai PID dari controller. Nilai yang tepat akan sangat mempengaruhi kinerja respon Motor DC Seri yang didesain pada penelitian ini. Algoritma ant colony membutuhkan proses perhitungan sampai menemukan nilai yang optimal. Gambar berikut menunjukkan grafik konvergensi optimasi nilai PID menggunakan algoritma ant colony. Konvergensi adalah suatu nilai fitness function yang menjabarkan kriteria optimal dari suatu masalah optimasi.

Gambar 6 menunjukkan grafik konvergensi optimasi nilai PID menggunakan ant colony, di mana berdasarkan grafik terlihat algoritma ant colony tidak membutuhkan waktu yang lama dalam melakukan proses optimasi, hal tersebut terlihat pada iterasi ke 19 algoritma sudah menemukan nilai PID yang optimal dengan nilai fitness sebesar 111.8087. Untuk hasil selengkapnya dapat dilihat pada table berikut ini. 


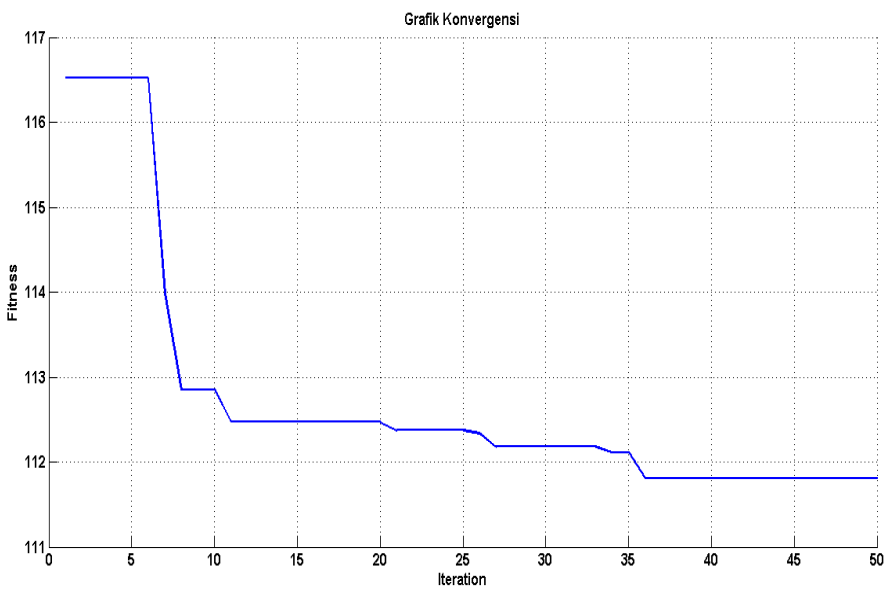

Gambar 6. Grafik Konvergensi Optimasi Kontrol PID Motor DC Seri dengan Ant Colony Optimization (ACO)

Tabel 2. Hasil Optimasi dengan ACO

Total number of iterations $=50$

fmin $=111.8087$

T_best $=23.0337 \quad 7.9168 \quad 7.8163$

kp_ant $=23.0337$

$\mathrm{ki}$ ant $=7.9168$

$\mathrm{kd} \_$ant $=7.8163$

Hasil optimasi ant colony didapatkan nilai fitness function sebesar 111.8087, dengan 50 kali iterasi, nilai nbest merupakan ant colony terbaik, yang di mana diketahui sebagai hasil optimasi parameter PID, yaitu $\mathrm{Kp}$, Ki dan Kd. Tabel 4 menunjukkan nilai hasil optimasi parameter PID ditala oleh ant colony. Sebagai pembanding digunakan kendali PID yang ditunning dengan cara trial error atau coba-coba. Algoritma Ant Coloni pada prinsipnya mencari sumber makanan berdasarkan jejak feromone yang kemudian secara berkelompok akan mengikuti jejak yang memiliki feromone yang terbesar. Dengan prinsip ini algoritma akan mencari parameter yang paling optimal untuk diisikan pada parameter PID, sehingga didapatkan kendali optimal pada kecepatan Motor DC Seri.

Tabel 3 Hasil Penalaan Parameter PID

\begin{tabular}{ccc}
\hline Param. & Trial Error & Ant Colony \\
\hline $\mathrm{Kp}$ & 4.1476 & 23.0337 \\
$\mathrm{Ki}$ & 0.2364 & 7.9168 \\
$\mathrm{Kd}$ & 0.8986 & 7.8163 \\
\hline
\end{tabular}

\section{HASIL SIMULASI DAN ANALISIS}

Dalam penelitian untuk mempermudah proses komputasi algoritma, kecepatan motor dc dituliskan dengan satuan pu (per unit). Sistem per-unit digunakan untuk menyederhanakan perhitungan numeric. Sistem per-unit secara sederhana merupakan metode pen-skalaan. Sistem per-unit direpresentasikan dengan nilai aktual kecepatan motor dengan base value. Base value selalu memiliki unit yang sama dengan actual value, sehingga nilai per-unit tidak memiliki satuan.

\subsection{Respon Kecepatan Motor DC Seri tanpa Kontrol}

Analisa pertama dimulai dengan melihat kinerja Motor DC Seri tanpa kontrol. Berikut hasil simulasi dengan menggunakan Matlab. Dengan beberapa variasi perubahan kecepatan motor dan perubahan beban, akan dilihat respon motor dalam mentracking setpoint yang diberikan. 


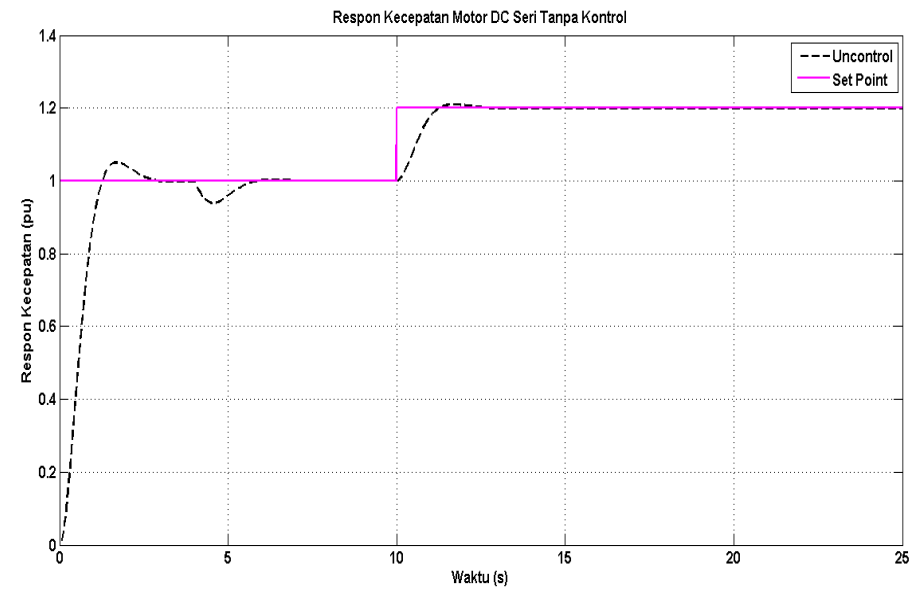

Gambar 7. Respon Kecepatan Motor DC Seri tanpa kontrol, untuk t=25s.

Gambar 7 menunjukkan hasil simulasi tanpa kontroler dengan $\mathrm{t}=25 \mathrm{~s}$, didapatkan respon kecepatan Motor DC Seri yang sangat lambat, bahkan tidak mencapai setpoint yang sudah ditentukan. Hal ini dikarenakan sistem tidak mempunyai kontroler kecepatan. Hasil simulasi system tanpa kontrol ini dijadikan acuan untuk mendesain kendali motor berbasis PID yang ditunning dengan algoritma cerdas menggunakan Ant Colony Optimization, dan sebagai pembanding digunakan metode PID yang ditune secara trialerror/coba-coba. Berikut hasil simulasi kontrol Motor DC Seri tanpa kontrol.

Tabel 4 Respon Overshoot Sistem

\begin{tabular}{ccc}
\hline Case & Case Speed (pu) & Overshoot (pu) \\
\hline 1 & Kecepatan 1pu & 1.05 \\
2 & Beban 0.4pu (4s) & 0.92 \\
3 & Kecepatan 1.2pu (10s) & 1.21 \\
\hline
\end{tabular}

Table 4 menunjukkan respon overshoot kecepatan Motor DC Seri tanpa kontrol, di mana digunakan 3 case variasi kecepatan dan perubahan beban. Case pertama variasi kecepatan sebesar 1pu, respon motor mengalami overshoot maksimum hingga $1.05 \mathrm{pu}$. Case kedua perubahan beban pada $\mathrm{t}=4 \mathrm{~s}$ sebesar $0.4 \mathrm{pu}$, respon motor mengalami osilasi overshoot minimum sebesar 0.92pu. Case ketiga kecepatan dinaikkan ke $1.2 \mathrm{pu}$, respon motor mengalami overshoot hingga 1.21pu. Selain overshoot, kinerja system juga dapat ditinjau dari kriteria settling time, di mana menunjukkan settling time yang lama untuk masing-masing variasi kecepatan untuk mencapai kondisi yang sama dengan setpoint yang diberikan. Kinerja system juga dapat dilihat ketika terjadi perubahan beban pada $\mathrm{t}=0.4 \mathrm{~s}$, system mengalami osilasi overshoot minimum, sehingga mengganggu kinerja dari motor dc seri.

Dari hasil simulasi motor de seri tanpa kontrol ini dijadikan referensi awal untuk mendesain system dengan kontroler PID berbasis metode cerdas ant colony.

\subsection{Respon Kecepatan Motor DC Seri dengan Kendali PID Trial Error}

Analisa berikutnya, melihat kinerja respon kecepatan Motor DC Seri dengan pemasangan kontrol PID, di mana parameter PID di tunning menggunakan cara trial error, berikut hasil simulasinya. 


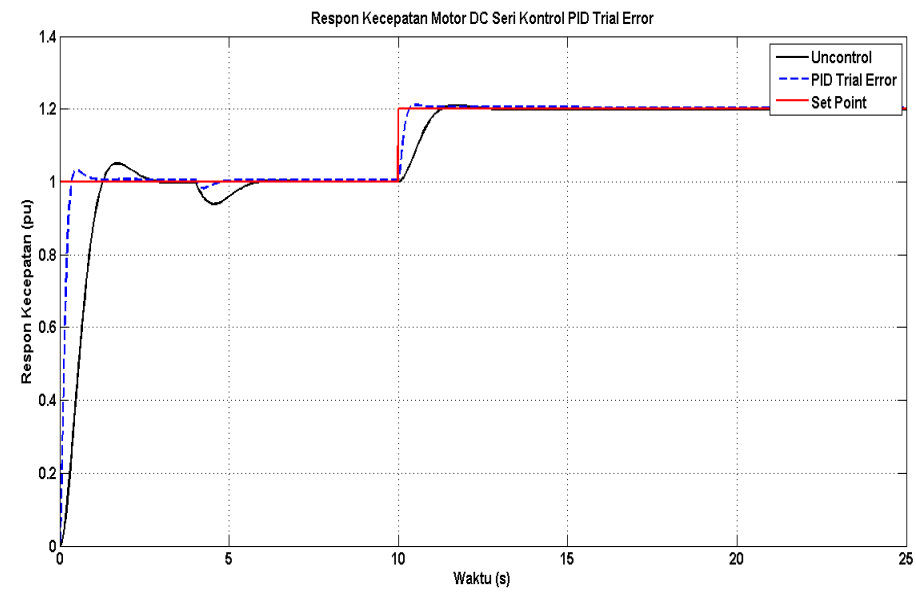

Gambar 8. Respon Kecepatan Motor DC Seri dengan PID Trial, $\mathrm{t}=25 \mathrm{~s}$

Gambar 8 menunjukkan hasil simulasi dengan kontroler PID yang ditune dengan trial error, dengan $\mathrm{t}=25 \mathrm{~s}$. Dari desain tersebut didapatkan respon kecepatan Motor DC Seri yang membaik dibanding dengan system tanpa kontrol, ditunjukkan dengan overshoot yang berkurang. Berikut hasil simulasi kontrol Motor DC Seri dengan PID trial error.

Tabel 5. Respon Overshoot Sistem

\begin{tabular}{ccc}
\hline Case & Case Speed (pu) & Overshoot (pu) \\
\hline 1 & Kecepatan 1pu & 1.03 \\
2 & Beban 0.4pu (4s) & 0.98 \\
3 & Kecepatan 1.2pu (10s) & 1.21 \\
\hline
\end{tabular}

Table 5 menunjukkan respon overshoot kecepatan Motor DC Seri kontrol PID trial error, di mana digunakan 3 case variasi kecepatan dan perubahan beban. Case pertama variasi kecepatan sebesar 1pu, respon motor mengalami overshoot maksimum hingga $1.03 \mathrm{pu}$. Case kedua perubahan beban pada $\mathrm{t}=4 \mathrm{~s}$ sebesar $0.4 \mathrm{pu}$, respon motor mengalami osilasi overshoot minimum sebesar 0.98pu. Case ketiga kecepatan dinaikkan ke 1.2pu, respon motor mengalami overshoot hingga 1.21pu. Selain overshoot, kinerja system juga dapat ditinjau dari kriteria settling time, di mana menunjukkan settling time yang membaik dibanding dengan kondisi system yang tanpa kontrol. Ditunjukkan dengan masing-masing variasi kecepatan yang mampu mendekati setpoint yang diberikan. Kinerja system juga dapat dilihat ketika terjadi perubahan beban pada $\mathrm{t}=0.4 \mathrm{~s}$, system mengalami perbaikan dengan osilasi overshoot minimum sebesar $0.98 \mathrm{pu}$,

Namun kinerja PID pada system ini masih bisa dioptimalkan dengan penalaan yang tepat. Pada metode ini parameter P (Proportional) sebesar 4.1476, I (Integral) sebesar 0.2364, dan D (Derivative) sebesar 0.8986. Parameter ini pada prinsipnya belum optimal dikarenakan kinerja system masih terdapat error dari set point yang sudah ditentukan.

\subsection{Respon Kecepatan Motor DC Seri dengan PID Ant Colony Optimization}

'Simulasi berikutnya adalah kontrol Motor DC Seri dengan menggunakan PID yang ditunning menggunakan algoritma ACO, berikut hasil simulasinya. 


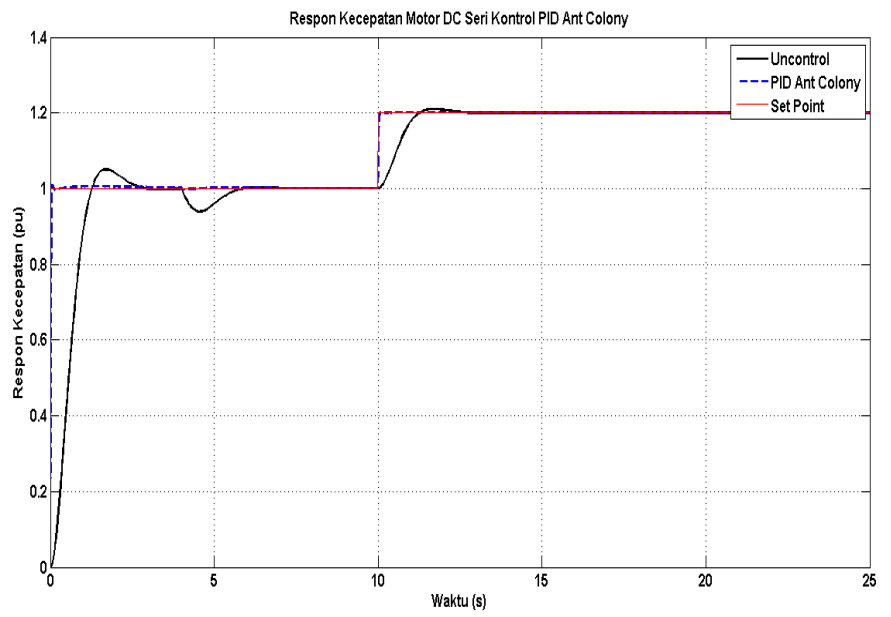

Gambar 9. Respon Kecepatan Motor DC Seri dengan PID Ant-Colony, t=25s

Gambar 9 menunjukkan hasil simulasi dengan kontroler PID yang ditune dengan metode cerdas ant colony, dengan $\mathrm{t}=25 \mathrm{~s}$. Dari desain tersebut didapatkan respon kecepatan Motor DC Seri yang sempurna dibanding dengan system tanpa kontrol dan kontrol PID trial error, hal ini ditunjukkan dengan overshoot yang berkurang. Berikut hasil simulasi kontrol Motor DC Seri dengan PID Ant Colony.

Tabel 6. Respon Overshoot Sistem

\begin{tabular}{ccc}
\hline Case & Case Speed (pu) & Overshoot (pu) \\
\hline 1 & Kecepatan 1pu & 1.002 \\
2 & Beban 0.4pu (4s) & 1 \\
3 & Kecepatan 1.2pu (10s) & 1.2 \\
\hline
\end{tabular}

Table 6 menunjukkan respon overshoot kecepatan Motor DC Seri kontrol PID ant colony, di mana digunakan 3 case variasi kecepatan dan perubahan beban. Case pertama variasi kecepatan sebesar 1pu, respon motor hanya mengalami overshoot sebesar $1.002 \mathrm{pu}$. Case kedua perubahan beban pada $\mathrm{t}=4 \mathrm{~s}$ sebesar $0.4 \mathrm{pu}$, respon motor steady/tetap pada setpoint awal yaitu 1pu. Case ketiga kecepatan dinaikkan ke 1.2pu, respon motor juga steady pada setpoint awal 1.2pu. Selain overshoot, kinerja system juga dapat ditinjau dari kriteria settling time, di mana menunjukkan settling time yang sempurna dibanding dengan kondisi system yang tanpa kontrol dan PID trial error. Ditunjukkan dengan masing-masing variasi kecepatan yang sama dengan setpoint yang diberikan. Kinerja system juga dapat dilihat ketika terjadi perubahan beban pada $\mathrm{t}=0.4 \mathrm{~s}$, system mampu bertahan sesuai dengan setpointnya,. Berikut grafik perbandingan kontrol motor dc seri.

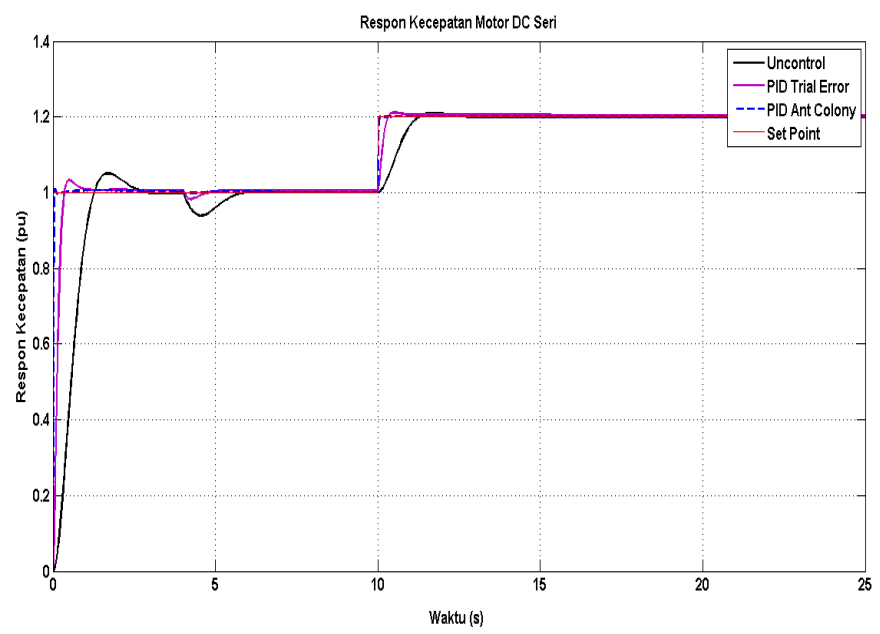

Gambar 10. Perbandingan respon Kecepatan Motor DC Seri dengan PID Ant-Colony, t=10s 
Algoritma Ant Colony pada prinsipnya mencari sumber makanan berdasarkan jejak feromone yang kemudian secara berkelompok akan mengikuti jejak yang memiliki feromone yang terbesar. Dengan prinsip ini algoritma akan mencari parameter yang paling optimal untuk diisikan pada parameter PID, sehingga didapatkan kendali optimal pada kecepatan Motor DC Seri. Pada hasil penalaan metode cerdas, didapatkan parameter PID yang optimal, parameter P (Proportional) sebesar 23.0337, I (Integral) sebesar 7.9168, dan D (Derivative) sebesar 7.8163. Dengan kombinasi parameter yang optimal ini didapatkan kinerja respon kecepatan Motor DC Seri yang optimal, ditandai dengan respon settling time kecepatan motor yang cepat dan overshoot yang minimum dibanding dengan metode PID trial dan system tanpa kontrol.

Aplikasi Motor DC Seri sangat banyak digunakan dengan kombinasi kendali PID, sehingga dibutuhkan desain kontroler Motor DC Seri yang tepat, dalam hal ini sangat diusulkan untuk menggunakan kontroler PID karena sangat simple untuk pengontrolan sistem dengan penalaan parameter menggunakan metode cerdas yang tepat akan didapatkan kinerja yang baik.

\section{KESIMPULAN}

Algoritma Ant Coloni pada prinsipnya mencari sumber makanan berdasarkan jejak feromone yang kemudian secara berkelompok akan mengikuti jejak yang memiliki feromone yang terbesar. Dengan prinsip ini algoritma akan mencari parameter yang paling optimal untuk diisikan pada parameter PID, sehingga didapatkan kendali optimal pada kecepatan Motor DC Seri.

Hasil optimasi ant colony didapatkan nilai fitness function sebesar 79.4892, dengan 50 kali iterasi, dan parameter nilai PID yang optimal di mana, parameter P (Proportional) sebesar 23.0337, I (Integral) sebesar 7.9168, dan D (Derivative) sebesar 7.8163.

Dengan beberapa case kecepatan dan perubahan beban pada Motor DC Seri, dengan kendali PID Ant Colony didapatkan kinerja system optimal dengan overshoot yang minimum dan settling yang cepat.

\section{DAFTAR PUSTAKA}

[1] J. Chakravorty and R. Sharma, "Fuzzy Logic Based Method of Speed Control of DC Motor," International Journal of Emerging Technology and Advanced Engineering (IJETAE), vol. 3, 2013.

[2] J. R. Castro and O. Castillo, "Interval Type-2 Fuzzy Logic for Intelligent Control Applications," in Fuzzy Information Processing Society, 2007. NAFIPS'07. Annual Meeting of the North American, 2007, pp. 592-597.

[3] M. R. Djalal, D. Ajiatmo, A. Imran, and I. Robandi, "Desain Optimal Kontroler PID Motor DC Menggunakan Cuckoo Search Algorithm," SENTIA 2015, vol. 7, 2015.

[4] Q. Aliklas, N. Satyahadewi, and H. Perdana, "PENERAPAN ALGORITMA MAX-MIN ANT SYSTEM DALAM PENYUSUNAN JADWAL MATA KULIAH DI JURUSAN MATEMATIKA FMIPA UNTAN," BIMASTER, vol. 8.

[5] M. E. El-Telbany, "Tuning PID controller for DC motor: An artificial bees optimization approach," International Journal of Computer Applications, vol. 77, 2013.

[6] M. I. Solihin, L. F. Tack, and M. L. Kean, "Tuning of PID controller using particle swarm optimization (PSO)," International Journal on Advanced Science, Engineering and Information Technology, vol. 1, pp. 458-461, 2011.

[7] M. R. Djalal, M. Y. Yunus, A. Imran, and H. Setiadi, "FLOWER POLLINATION ALGORITHM UNTUK OPTIMASI PENGENDALI PID PADA PENGENDALIAN KECEPATAN MOTOR INDUKSI," JETri Jurnal Ilmiah Teknik Elektro, pp. 81-100, 2017.

[8] L. Dwi, R. D. Muhammad, W. Widodo, and R. Imam, "Optimization of PID Controller Design for DC Motor Based on Flower Pollination Algorithm," 2016.

[9] M. R. Djalal, H. Nurohmah, A. Imran, and M. Y. Yunus, "Aplikasi Metode Cerdas untuk Optimasi Controller PID Motor DC Berbasis Firefly Algorithm," Jurnal Nasional Teknik Elektro, vol. 6, pp. 76-83, 2017.

[10] M. R. Djalal and R. Rahmat, "OPTIMISASI KONTROL PID UNTUK MOTOR DC MAGNET PERMANEN MENGGUNAKAN PARTICLE SWARM OPTIMIZATION," Jurnal TAM (Technology Acceptance Model), vol. 8, pp. 117-122, 2017.

[11] A. Asri, M. R. Djalal, and R. Rahmat, "DESAIN OPTIMAL KONTROLER PROPORSIONAL INTEGRAL MOTOR DC MENGGUNAKAN ALGORITME PARTICLE SWARM OPTIMIZATION," JETri Jurnal Ilmiah Teknik Elektro, vol. 15, pp. 155-170, 2018.

[12] M. R. Djalal, A. Pangkung, M. Marhatang, and S. Sonong, "FIELD-ORIENTED CONTROL PERMANENT MAGNET MOTOR SINKRON MENGGUNAKAN ALGORITMA KUNANG-KUNANG," Jurnal Teknologi, vol. 10, pp. 153-160, 2018.

[13] M. R. Djalal, "Modifikasi Desain PID Controller Pada Permanent Magnet Synchronous Motor Dengan Flower Pollination Algorithm."

[14] M. Tushir and S. Srivastava, "Type-2 fuzzy logic controller Implementation for tracking control of DC motor," International Journal of Computer Network and Security (IJCNS) vol. 3. 